\title{
Analisis Video Comments to Followers Ratio Instagram Pada 6 Artis Indonesia dengan Followers Instagram Terbanyak
}

\author{
I Gede Jaya Pratama \\ gede.jaya78@gmail.com
}

\begin{abstract}
Instagram is one of the social media that was founded by Burn Inc in 2010. Instagram allows its users to share our everyday photos and videos and can create videos, music, filters with user creativity. In Indonesia, the number of Instagram users is more than 300 million active users. make Instagram has many fans because of its features. There are many Instagram enthusiast platforms that make people develop creativity and popularity today, such as 6 Indonesian Artists with the most Instagram Followers, including: Gisella Anastasia, Laudya Cintya Bella, Syahrini, Prilly Latuconsina, Ayu Ting Ting, and Raffi Ahmad and Nagita Slavina. The purpose of this study is to calculate the performance of the Instagram account of 6 artists with the most followers in Indonesia. The method used in this study is quantitative exploratory, from the results of this study it can be shown that 6 Indonesian Artists with the most Followers with Video Comments to Followers Ratio Analysis prove the highest by Prilly Latuconsina with a value of 0.00002181 .
\end{abstract}

\begin{abstract}
ABSTRAK
Instagram merupakan salah satu media sosial yang didirikan oleh Burn Inc pada tahun 2010. Instagram memungkinkan penggunaya untuk berbagi foto dan video keseharian kita dan dapat membuat video, music, filter dengan kreatifitas penggunanya, Di Indonesia jumlah pengguna Instagram lebih dari 300 juta pengguna aktif menjadikan Instagram memiliki banyak peminat karna fitur - fiturnya. Banyaknya peminat platform Instagram ini menjadikan orang - orang dalam mengembangkan kreatifitas dan meraih popularitas, saat ini seperti 6 Artis Indonesia dengan Follower Instagram terbanya, diantaranya seperti : Gisella Anastasia, Laudya Cintya Bella, Syahrini, Prilly Latuconsina, Ayu Ting Ting, dan Raffi Ahmad dan Nagita Slavina. Tujuan dari penelitian ini yaitu untuk menghitung kredibilitas dari performance akun Instagram 6 Artis dengan Followers terbanyak di Indonesia. Metode yang digunakan dalam penelitian ini yaitu Eksploratif Kuantitatif, dari hasil penelitian ini dapat menunjukkan bahwa 6 Artis Indonesia dengan follower terbanyak dengan Analisis Video Comments to Followers Ratio membuktikan kredibilitas paling tinggi oleh Prilly Latuconsina dengan nilai 0.00002181 .
\end{abstract}

Keyword : Credibility Account Instagram ; Social Media Instagram ; IG ; Video Comments to Followers Ratio ; Artis dengan followers terbanyak di Indonesia. 


\section{PENDAHULUAN}

Pada masa dijaman yang modern ini kemajuan teknologi telah berkembang pesat dan dengan berkembangnya teknologi akan semakin majunya manusia dan menciptakan cara yang baru pula dalam berinteraksi seperti saat ini manusia banyak berinteraksi secara tidak langsung, tetapi melalui media social. Peranan media social ini berpengaruh besar terhadap gaya sosialisai masyarakat dimana setiap aktiftas pada keseharian manusia saat ini dilakukan di dunia maya melalui berbagai macam platform media social yang tersedia, komunikasi yang dapat dilakukan tidak secara fisik dan dapat berinteraksi, bertukar informasi, berbagi pengalaman, dan membagikan momen-momen penting dalam media social dan memberikan ruang terbuka dalam berkomunikasi antar manusia.

Saat ini media sosial berkembang sangat pesat salah satunya yaitu media sosial Instagram. Instagram merupakan salah satu media sosial terpopuler di dunia. Aplikasi yang digunakan untuk memposting foto atau video dengan fitur yang menarik ini mampu memikat perhatian banyak orang. Namun tidak banyak pula yang mengetahui sejarah serta perkembangan media sosial tersebut. Mulai dari terciptanya aplikasi Instagram yang awalnya hanya dapat memposting foto atau video serta menyertakan tanda suka dan komentar, kini berkembang dengan bertambahnya fitur-fitur lainnya. Yang awalnya hanya sekedar berbagi foto atau video namun menjadi meluas bahkan merambah ke dunia bisnis. Mengingat perkembangan teknologi yang semakin maju dalam media sosial. Maka dari itu, penulis akan memaparkan bagaimana sejarah terciptanya media sosial Instagram termasuk perkembangannya hingga saat ini (Indriani, n.d.). Dengan berkembangnya sosial media Instagram saat ini di Indonesia ada 6 artis dengan jumlah followers terbanyak seperti : Gisella Anastasia, Laudya Cintya Bella, Syahrini, Prilly Latuconsina, Ayu Ting Ting, Raffi Ahmad dan Nagita Slavina. ("6 Artis Indonesia Dengan Followers Instagram Terbanyak, Ayu Ting Ting Tak Lagi Nomor Satu” n.d.)

Metode penelitian yang digunakan adalah metode deskriptif eksploratif dengan pendekatan kualitatif (Aprilia and Kesehatan 2015), untuk menemukan variabel-variabel yang terdapat pada akun Instagram. Penelitian ini dilakukan dengan tujuan untuk menemukan rasio-rasio yang terdapat pada akun Instagram. Rasio-rasio ini yang nantinya akan digunakan untuk mengukur performa sebuah akun secara matematis. Variabel tersebut yang nantinya akan dibandingkan dan disandingkan untuk diuji relevansinya sehingga menjadi rasio yang relevan. Rasio yang relevan akan digunakan untuk menilai performa 6 akun yang ada pada social media Instagram dengan menggunakan Video Comments to Follower Ratio. 


\section{TINJAUAN PUSTAKA}

Instagram adalah salah satu aplikasi yang gunanya untuk berbagi foto yang memungkinkan pengguna menggambil foto, menerapkan filter digital, dan membagikannya ke berbagai layanan jejaring sosial, termasuk milik instagram sendiri. Instagram juga menjadi wadah untuk membentuk citra diri, dimana semakin banyak angka followers atau pengikut dan like (menyukai) di beberapa foto si pemilik akun akan semakin terlihat bahwa si pengguna memiliki citra diri yang tinggi, juga dapat menjadi figur bagi remaja- remaja masa kini (Zakirah 2018).

Perkembangan teknologi yang sangat cepat berbanding lurus dengan perkembangan sosial media (SESRIYANI and SUKMAWATI 2019), dan dapat ditarik kesimpulan dari pernyataan tersebut bahwa Instagram merupakan sebuah aplikasi jejaring sosial yang memungkinkan penggunanya untuk berbagi foto maupun video bahkan dapat secara otomatis terhubung dengan platform jejaring sosial lainnya.

Peluncuran Instagram pertama kali berlangsung sukses karena tidak menggunakan iklan, hanya mengandalkan viral marketing yang berhasil menjaring 25 ribu pengguna di hari pertama. Di masa-masa awal ini, Kevin dan Mike hanya menggunakan kotak kecil di pengelolaan data center untuk menyimpan foto-foto dari pengguna. Dalam waktu seminggu saja, penggunanya telah berjumlah 100 ribu orang. Maka dengan cepat pula Kevin dan Mike melakukan upgrade. Seluruh situs Instagram dipindah ke layanan berbasis Cloud Amazon yang lebih kredibel. Dalam waktu singkat buzz di jejaring sosial terutama twitter membuat aplikasi ini semakin populer karena berada di trending topic dalam waktu yang cukup lama. Dalam waktu sekitar 2,5 bulan pengguna Instagram dengan cepat telah meningkat menjadi satu juta orang Namun tujuan dibuatnya Instagram bukanlah hanya sebuah aplikasi foto, melainkan sebuah cara baru berkomunikasi lewat gambar dan merupakan komunikasi yang berbeda. Karena aplikasi pengolah foto adalah sebuah alat (Difika 2016). Indonesia sendiri adalah salah satu negara dengan jumlah pengguna instagram terbanyak dengan 89 persen Instagrammers yang berusia 18-34 tahun mengakses IG (Instagram) setidaknya seminggu sekali.Instagrammers mayoritas anak muda, terdidik, dan mapan. Rata-rata mereka berusia 18-24 tahun sebanyak 59 persen, usia 45-34 tahun 30 persen, dan yang berusia 34-44 tahun 11 persen. Pengguna IG perempuan yang paling aktif sebanyak 63 persen dan laki-laki 37 persen (Prihatiningsih 2017).

Dapat dilihat dari perkembangan Instagram yang sangat pesat dari tahun ke tahun dimana Instagram tidak hanya dapat dipergunakan sebagi media social untuk sharing foto atau video bersama teman dan keluarga tapi juga bisa dimanfaatkan kedepanya untuk bisnis, penyebaran informasi untuk masyarakat umum. Kredibilitas sebuah akun Instagram dapat diukur dari tingkat performa yang dihasilkan secara matematis. Dalam mengukur performa diperlukan skala pengukuran yang tertuang ke dalam rasio. 


\section{METODOLOGI PENELITIAN}

Penelitian saat ini menggunakan metode yang bertipe eksploratif kuantitatif yang gunanya untuk meneliti kategori tertentu yang ingin di analisa dalam masyarakat yang menggunakan media social Instagram dengan tujuan memperdalam pengetahuan dan mencari ide-ide yang baru. Penelitian ini bisa di gunakan sebagai acuan penelitian kuantitatif sehingga suatu objek yang di analisis memiliki nilai berupa angka yang bisa di dihitung dalam memformulasikan sebagai rasio. Namun diantara beberapa penelitian yang sudah ada mengenai Instagram, belum ada peneliti yang meneliti tentang pencarian rasio - rasio yang dapat digunakan sebagai alat ukur dalam menilai berbagai aspek pada Instagram. Rasio - rasio ini yang nantinya dapat digunakan untuk melakukan analisa atau penelitian kuantitatif (Putu and Permana 2021).

Tujuan dari penelitian ini untuk mengetahui nilai kerdibillitas dari performa 6 Artis Indonesia dengan Follower terbanyak, ada beberapa langkah yang harus di lakukan guna untuk mendapatkan peringkat pertama artis dengan followers terbanyak di indonesia. Langkah-langkah yang harus di lakukan seperti :

\section{Melakukan eksplorasi pada media sosial Instagram untuk menentukan objek yang akan dianalisa.}

Eksplorasi adalah penjelajahan lapangan dengan tujuan memperoleh pengetahuan lebih banyak tentang keadaan (Onainor 2019). Eksplorasi ini dilakukan di beberapa halaman dan pencarian yang menyediakan banyak informasi tentang objek yang ingin di teliti. Setelah eksplorasi yang dilakukan sudah menemukan 6 artis dengan followers terbanyak yang akan dijadikan objek analisa. Eksplorasi yang sudah dilakukan di pada menu pencarian Instagram untuk memudahkan menentukan objek Analisa, jika sudah di lakukan pencarian maka selanjutnya mencari nama masing-masing ke 6 artis dengan followers terbanyak di Indonesia tersebut dimana akun Instagram yang sudah di tentukan harus dipastikan memiliki media sosial Instagram.

\section{Menghitung Nilai Rata-Rata Variabel dari 6 Artis dengan Followers terbanyak di Indonesia.}

Untuk langkah selanjutnya, saatnya peneliti melakukan penghitungan terhadap variabel yang ditentukan, yaitu Video Comments to Followers. Benar tidaknya data tergantung pada baik tidaknya instrumen pengumpul data atau pengukur objek dari suatu variabel penelitian (Yusup 2018). Nilai rata-rata dari variabel Video Comments dan jumlah dari followers Instagram objek analisa dapat di cari dengan cara mengambil minimal 10 postingan video dan dijumlahkan untuk menemukan nilai rata-rata dari variable Video Comments. 


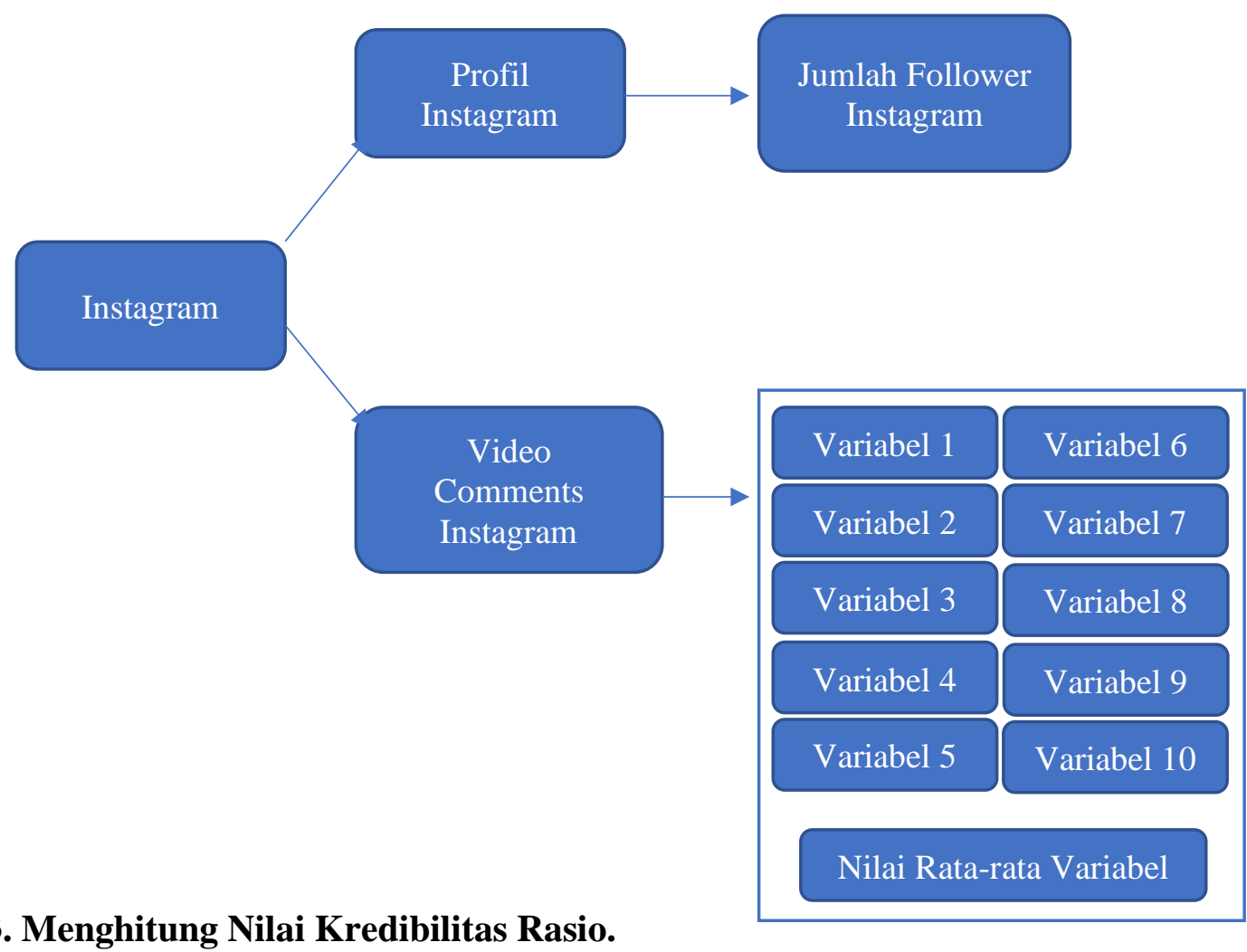

Untuk menghitung nilai kreadibilitas dari Video Comments to Followers ratio dari platform Instagram, peneliti menggunakan cara membagi nilai variabel Video Comment dan variable jumlah follower akun Instagram. Jika Video Comment memiliki jumlah komentar 430 dan denganFollowers 34.300 .000 ,maka cara menghitungnya 430 : $34.300 .000=0.00001254$. Dengan demikian nilai ratio dari Video Comment to Followers ratio 0.00001254 .

\section{Menentukan Peringkat Dari 6 Artis Indonesia Dengan Followers Terbanyak.}

Langkah ini merupakan langkah terakhir yang di lakukan pada penelitian ini yaitu menentukan peringkat. Pada menentukan peringkat perlu melihat karakteristik dari setiap ratio yang di teliti. Jika karakteristik dari ratio tersebut rendah akan mendapatkan nilai 6 dan jika tinggi akan mendapatkan nilai 1, jika karakteristik tinggi maka yang mendapatkan nilai tinggi akan mendapatkan peringkat 6 dan yang rendah akan mendapatkan nilai 1 . 


\section{HASIL DAN PEMBAHASAN}

Akun Instagram dari 6 Artis Indonesia dengan Followers Instagram Terbanyak, diantaranya :

\section{Gisella Anastasia}

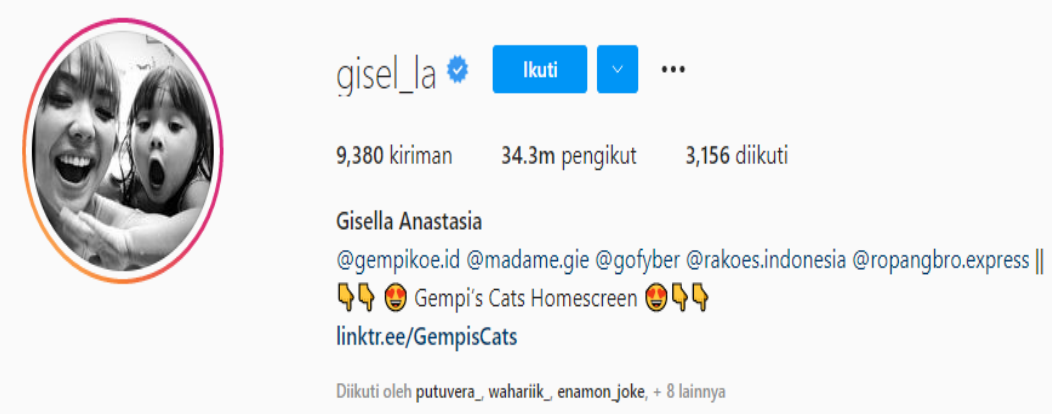

Gambar 1. Akun Instagram Gisella Anastasia

Sumber : https://www.instagram.com/gisel_la/ (akses pada 22-10-2021)

\section{Laudya Cintya Bella}

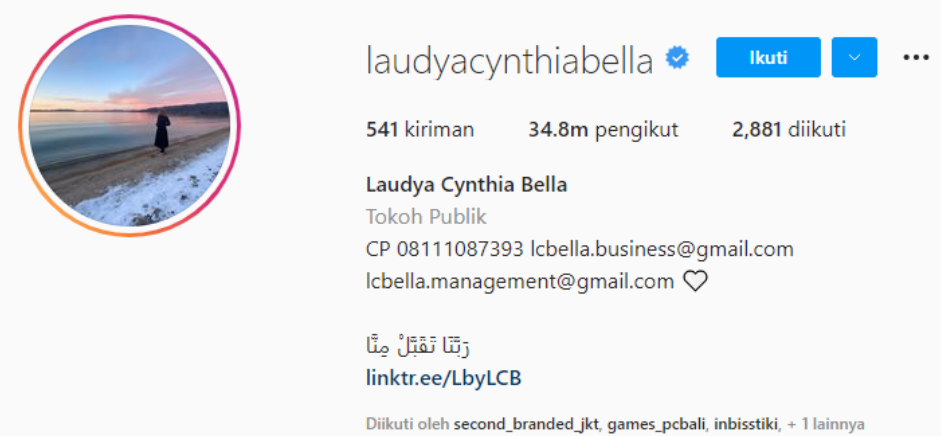

Gambar 2. Akun Instagram Laudya Cintya Bella

Sumber : https://www.instagram.com/laudyacynthiabella/ (akses pada 22-10-2021)

\section{Syahrini}
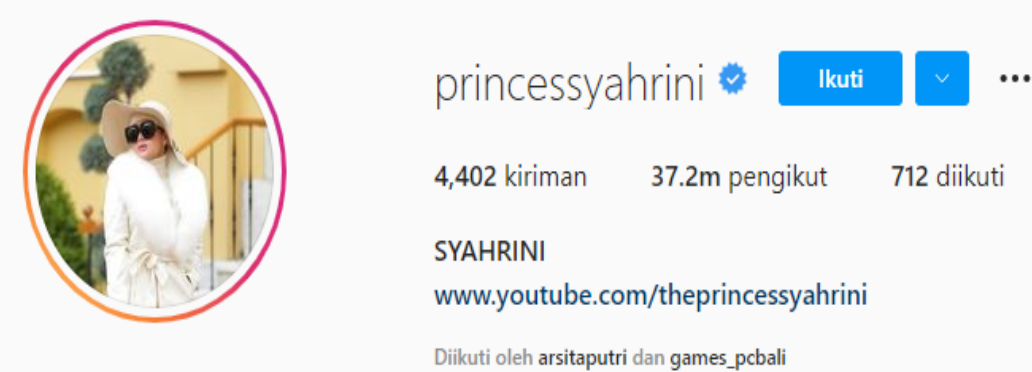

Gambar 3. Akun Instagram Syahrini

Sumber : https://www.instagram.com/princessyahrini/ (akses pada 22-10-2021) 


\section{Prilly Latuconsina}

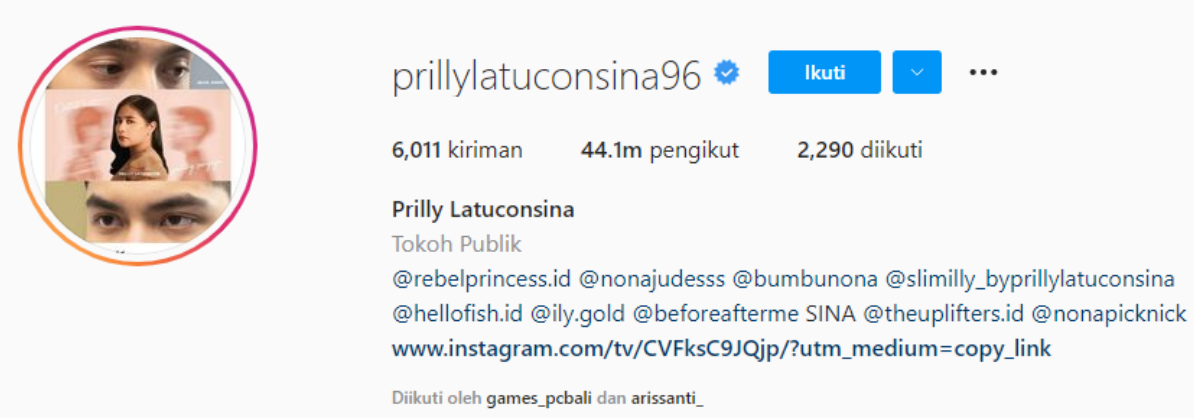

Gambar 4. Akun Instagram Prilly Latuconsina

Sumber : https://www.instagram.com/prillylatuconsina96/ (akses pada 22-10-2021)

\section{Ayu Ting Ting}

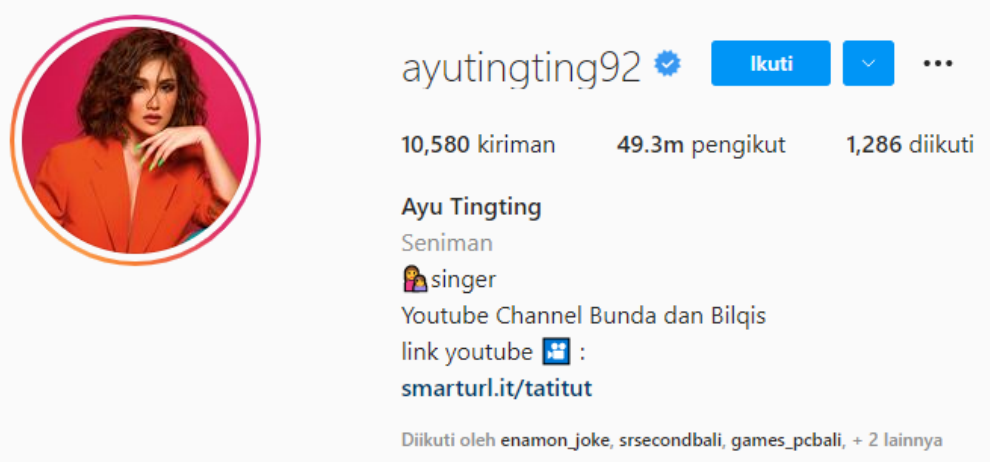

Gambar 5. Akun Instagram Ayu Ting Ting

Sumber : https://www.instagram.com/ayutingting92/ (akses pada 22-10-2021)

\section{Raffi Ahmad dan Nagita Slavina}
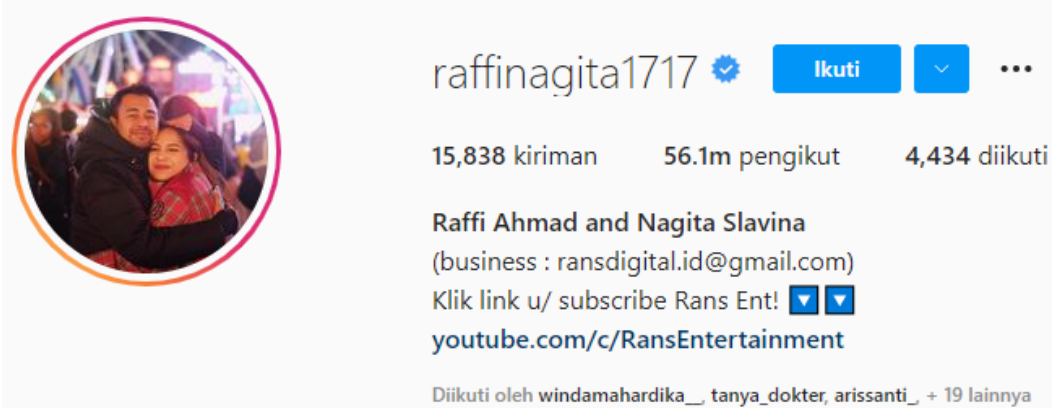

Gambar 5. Akun Instagram Raffi Ahmad dan Nagita Slavina

Sumber : https://www.instagram.com/raffinagita1717/ (akses pada 22-10-2021) 
Dari Keenam akun Instagram yang memiliki follower terbanyak di Indonesia, peneliti menemukan nilai dari masing-masing variabel yang ada untuk menghitung Video Comments to Followers Ratio Instagram dari setiap akun. Pada akun Instagram dan terdapat 7 variabel, diantaranya yaitu :

1. Likes

2. Followers

3. Following

4. Video Likes

5. Video Comments

6. Video Share

7. Video Views

Dari ketujuh variabel tersebut peneliti hanya fokus untuk menemukan hasil dari 2 variabel, yaitu :

1. Video Comments

2. Followers

Dari kedua variabel tersebut kemudian dianalisa sehingga menemukan nilai rata-rata dari Video Comments dan menentukan total follower pengguna Instagram. Untuk menghitung nilai rata-rata dari Video Commnets dengan cara mengambil jumlah Video Commnets pada postingan akun Instagram kemudian di hitung sehingga menemukan nilai rata-rata dari variabel tersebut. Berikut merupakan tabel nilai rata-rata dari 6 akun Instagram dengan follower terbanyak di Indonesia, yaitu :

Tabel 1. Analisa Nilai Rata-Rata Nilai Video Comments dan jumlah followers dari Gisella Anastasia, Laudya Cintya Bella, Syahrini, Prilly Latuconsina, Ayu Ting Ting, Raffi Ahmad dan Nagita Slavina

\begin{tabular}{|c|l|c|c|}
\hline No & \multicolumn{1}{|c|}{ Instagram } & Video Comments & Followers \\
\hline 1 & Gisella Anastasia & 430 & 34300000 \\
\hline 2 & Laudya Cintya Bella & 386.2 & 34800000 \\
\hline 3 & Syahrini & 0 & 0 \\
\hline 4 & Prilly Latuconsina & 959.5 & 44000000 \\
\hline 5 & Ayu Ting Ting & 442.8 & 49200000 \\
\hline 6 & Raffi Ahmad dan Nagita Slavina & 900.6 & 55900000 \\
\hline
\end{tabular}

Sumber : Pengolah Data Excel 
Setelah menghitung nilai rata-rata tersebut, maka akan menemukan hasil akhir nilai ratarata dari variabel video comments dan jumlah followers

Tabel 2. Nilai Variabel Pada 6 Followers akun Instagram terbnayak di Indonesia

\begin{tabular}{|c|c|c|c|c|c|c|}
\hline \multicolumn{7}{|c|}{ Tabel Nilai Masing-Masing Variable } \\
\hline Variable & $\begin{array}{c}\text { Gisella } \\
\text { Anastasia }\end{array}$ & $\begin{array}{c}\text { Laudya } \\
\text { Cintya } \\
\text { Bella }\end{array}$ & Syahrini & $\begin{array}{c}\text { Prilly } \\
\text { Latuconsina }\end{array}$ & $\begin{array}{c}\text { Ayu Ting } \\
\text { Ting }\end{array}$ & $\begin{array}{c}\text { Raffi } \\
\text { Ahmad dan } \\
\text { Nagita } \\
\text { Slavina }\end{array}$ \\
\hline $\begin{array}{c}\text { Video } \\
\text { Comments }\end{array}$ & 430 & 386.2 & 0 & 959.5 & 442.8 & 900.6 \\
\hline Followers & 34300000 & 34800000 & 37100000 & 44000000 & 49200000 & 55900000 \\
\hline
\end{tabular}

Sumber : Pengolah Data Excel

Pada akun Instagram terdapat 17 rasio yang relevan digunakan untuk mengukur kredibilitas pada masing-masing akun. Namun pada penelitian kali ini hanya berfokus untuk menghitung Video Comments to Followers Ratio. Untuk menghitung kredibilitas dari masing-masing akun Instagram, peneliti menghitung dengan cara : variabel 1 akan dibagi dengan variabel 2, sehingga ditemukan hasil analisisa dari rasio tersebut.

Tabel 3. Hasil Perhitungan Rasio Akun Instagram

\begin{tabular}{|c|c|c|c|c|c|c|c|}
\hline \multicolumn{8}{|c|}{ Tabel Rasio } \\
\hline No & Rasio & $\begin{array}{c}\text { Gisella } \\
\text { Anastasia }\end{array}$ & $\begin{array}{c}\text { Laudya } \\
\text { Cintya } \\
\text { Bella }\end{array}$ & Syahrini & $\begin{array}{c}\text { Prilly } \\
\text { Latuconsin } \\
\text { a }\end{array}$ & $\begin{array}{c}\text { Ayu Ting } \\
\text { Ting }\end{array}$ & $\begin{array}{c}\text { Raffi } \\
\text { Ahmad } \\
\text { dan Nagita } \\
\text { Slavina }\end{array}$ \\
\hline 1 & $\begin{array}{c}\text { Video } \\
\text { Comment } \\
\text { s to } \\
\text { Followers } \\
\text { Ratio }\end{array}$ & $\begin{array}{c}0.0000125 \\
4\end{array}$ & $\begin{array}{c}0.0000111 \\
0\end{array}$ & - & $\begin{array}{c}0.0000218 \\
1\end{array}$ & $\begin{array}{c}0.0000090 \\
0\end{array}$ & $\begin{array}{c}0.0000161 \\
1\end{array}$ \\
\hline
\end{tabular}

Sumber : Pengolah Data Excel

Video Commnets to Followers Ratio memiliki karakteristik yang Tinggi, artinya sehingga dapat dikatakan, semakin Tinggi angka/nilai yang dihasilkan maka semakin baik performa dari akun tersebut. Untuk memberikan peringkat pada masing-masing Akun Instagram, peneliti memberikan angka 6 kepada vendor yang mendapatkan nilai terendah dan angka 1 untuk Akun yang mendapatkan nilai tertinggi. Berikut merupakan tabel urutan nilai yang dihasilkan oleh masing-masing rata - rata variabel. 
Tabel 4. Nilai Rasio 6 Artis Indonesia dengan Followers Instagram Terbanyak

\begin{tabular}{|c|c|c|c|c|c|c|c|}
\hline \multicolumn{8}{|c|}{ Tabel Peringkat } \\
\hline No & Rasio & $\begin{array}{c}\text { Gisella } \\
\text { Anastasia }\end{array}$ & $\begin{array}{c}\text { Laudya } \\
\text { Cintya } \\
\text { Bella }\end{array}$ & Syahrini & $\begin{array}{l}\text { Prilly } \\
\text { Latuconsina }\end{array}$ & $\begin{array}{c}\text { Ayu Ting } \\
\text { Ting }\end{array}$ & $\begin{array}{c}\text { Raffi } \\
\text { Ahmad } \\
\text { dan Nagita } \\
\text { Slavina }\end{array}$ \\
\hline 1 & $\begin{array}{c}\text { Video } \\
\text { Comments } \\
\text { to } \\
\text { Followers } \\
\text { Ratio }\end{array}$ & 3 & 2 & 1 & 6 & 4 & 5 \\
\hline
\end{tabular}

Sumber : Pengolah Data Excel

Dari Tabel Nilai Rasio 6 Artis Indonesia dengan Followers Instagram Terbanyak dapat simpulkan bahwa Prilly Latuconsina mendapatkan nilai tertinggi untuk rasio Video Comments to Followers ratio. Sedangkan akun Instagram Syahrinit mendapatkan nilai terendah untuk rasio ini. Jadi, pada penelitian ini Prilly Latuconsina memiliki kredibilitas performa yang lebih baik dibandingkan dengan Syahrini yang lainnya.

\section{KESIMPULAN}

Tujuan dari penelitian ini adalah mengetahui kredibilitas performa dari 6 Artis Indonesia dengan Followers Instagram Terbanyak menggunakan Video Comments to Follower ratio. 6 Akun Instagram tersebut diantaranya : Gisella Anastasia, Laudya Cintya Bella, Syahrini, Prilly Latuconsina, Ayu Ting Ting, Raffi Ahmad dan Nagita Slavina. Dari keenam Artis Indonesia dengan Followers Instagram Terbanyak dapat disimpulkan bahwa :

1. Peringkat pertama diraih oleh Prilly Latuconsina dengan nilai tertinggi yaitu 0.00002181

2 Peringkat kedua diraih oleh Raffi Ahmad dan Nagita Slavina dengan nilai 0.00001611

3. Peringkat ketiga diraih oleh Ayu Ting Ting dengan nilai 0.00000900

4. Peringkat keempat diraih oleh Gisella Anastasia dengan nilai 0.00001254

5. Peringkat kelima diraih oleh Laudya Cintya Bella dengan nilai 0.00001110

6. Peringkat kelima diraih oleh Syahrini dengan nilai terendah yaitu 0 


\section{DAFTAR PUSTAKA}

"6 Artis Indonesia Dengan Followers Instagram Terbanyak, Ayu Ting Ting Tak Lagi Nomor Satu." n.d. Accessed December 4, 2021.

https://www.suara.com/entertainment/2021/08/26/191939/6-artis-indonesia-denganfollowers-instagram-terbanyak-ayu-ting-ting-tak-lagi-nomor-satu?page=all .

Aprilia, Astri, and Fakultas Kesehatan. 2015. "Perilaku Ibu Dalam Memberikan Pendidikan Seks Usia Dini Pada Anak Pra Sekolah (Studi Deskriptif Eksploratif Di TK IT Bina Insani Kota Semarang).” Vol. 3. http://ejournal-s1.undip.ac.id/index.php/jkm.

Difika, Fifit. 2016. "Dakwah Melalui Instagram (Studi Analisis Materi Dakwah Dalam Instagram Yusuf Mansur, Felix Siauw, Aa Gym, Arifin Ilham).” Walisongo Respository, 11-36. http://eprints.walisongo.ac.id/6462/.

Indriani, Eka. n.d. "SEJARAH DAN PERKEMBANGAN INSTAGRAM.”

—. 2017. "Sejarah Dan Perkembangan Instagram.” Ilmuti.Org. ilmuti.org.

Prihatiningsih, Witanti. 2017. "MOTIF PENGGUNAAN MEDIA SOSIAL INSTAGRAM DI KALANGAN REMAJA.” Communication 8 (1): 51.

https://doi.org/10.36080/COMM.V8I1.651.

Putu, I, and Hendika Permana. 2021. “Analisis Rasio Pada Instagram Untuk Penelitian Kualitatif Menggunakan Metode Ekploratif.” Jurnal Sistem Informasi Dan Komputer Terapan Indonesia (JSIKTI) 3 (3): 44-56. https://doi.org/10.22146/jsikti.

SESRIYANI, LODYA, and NUR NAJIBAH SUKMAWATI. 2019. “Analisis Penggunaan Instagram Sebagai Media Pembelajaran Bahasa Inggris Pada Program Studi Pendidikan Ekonomi." EDUKA : Jurnal Pendidikan, Hukum, Dan Bisnis 4 (1). https://doi.org/10.32493/eduka.v4i1.3822.

Yusup, Febrinawati. 2018. "Uji Validitas Dan Reliabilitas Instrumen Penelitian Kuantitatif." Jurnal Tarbiyah : Jurnal Ilmiah Kependidikan 7 (1): 17-23. https://doi.org/10.18592/tarbiyah.v7i1.2100.

Zakirah, Dinda Marta Almas. 2018. "Mahasiswa Dan Instagram (Study Tentang Instagram Sebagai Sarana Membentuk Citra Diri Di Kalangan Mahasiswa Universitas Airlangga).” Jurnal S1 Sosiologi FISIP Universitas Airlangga, 1-21. 